DOI: 10.46340/eppd.2021.8.2.17

Maryna Kalashlinska

ORCID ID: https://orcid.org/0000-0001-5825-3631

Maria Curie-Sklodowska University ${ }^{1}$, Lublin, Poland

\title{
IMPACT OF COVID-19 \\ ON THE FUNCTIONING OF POLISH SOCIETY: PALLIATIVE CARE ASPECT
}

\author{
Maryna Kalashlinska \\ Uniwersytet Marii Curie-Skłodowskiej, Lublin, Polska \\ WPLYW COVID-19 NA FUNKCJONOWANIE \\ POLSKIEGO SPOLECZEŃSTWA: \\ ASPEKT OPIEKI PALIATYWNEJ
}

The article deals with the impact of COVID-19 on the functioning of polish society in the palliative care aspect. The period 2020-2021 is characterized by the pandemic spread of COVID-19 around the world. COVID-19 is an acute respiratory disease caused by the novel human coronavirus (SARS-CoV2, also known as "COVID-19 disease virus"). In the media, more and more often the phenomenon of the impact of the disease on the life of society and its consequences is called "corona crisis". The COVID-19 pandemic caused a number of serious socio-economic consequences, including the largest global recession since the Great Depression. This led to the postponement or cancellation of many sports, religious, political and cultural events, work and learning began to take place remotely. All these tendencies have one thing in common-social distance. The coronavirus pandemic has significantly complicated the already difficult work of palliative care personnel around the world. On the one hand, palliative care in a pandemic is a system with actively increased needs and difficulties that requires extremely quick solutions to help the chronically ill. On the other hand, a system that can actively participate in helping patients with coronavirus infection to ensure quality of life and alleviate persistent problems and pain. Patients with severe, persistent symptoms of coronavirus infection may require palliative care too. In an epidemic situation, palliative care specialists can be effectively sought in intensive care units and intensive care units to work with heavy patients. This need may become particularly acute in the event of an increased flow of patients with severe symptoms and poor prognosis for recovery. In the situation of the coronavirus epidemic, when health systems in different countries make ad hoc organizational decisions due to a lack of a variety of resources, including human resources, palliative care and its patients find themselves in an extremely vulnerable situation, experiencing everyday difficulties in meeting their needs and goals. Changes in the possibility of providing and receiving services, occurring in an ultra short time, do not allow us to adapt to them without losing quality.

Keywords: COVID-19, Poland, corona crisis, palliative care, hospice care, WHO.

Wprowadzenie. Lata 2020-2021 charakteryzują się pandemicznym rozprzestrzenianiem się COVID19 na całym świecie - 30 stycznia 2020 WHO uznała wybuch COVID-19 za stan zagrożenia zdrowia publicznego o zasięgu międzynarodowym ${ }^{2}$. Pierwszy przypadek koronawirusa w Polsce wykryto 4 marca 2020 r. - pacjentem zero był 66-letni Mieczysław Opałka ${ }^{3}$, który przyjechał autobusem z Niemiec.

\footnotetext{
${ }^{1}$ Program Stypendialny im. Lane'a Kirklanda 2020/2021.

${ }^{2}$ Medonet.pl (2020). WHO ogłasza stan zagrożenia zdrowia publicznego o znaczeniu międzynarodowym <https://www.medonet.pl/zdrowie, who-oglasza-stan-zagrozenia-zdrowia-publicznego-o-znaczeniumiedzynarodowym,artykul,64750229.html> (2021, Luty, 27).

${ }^{3}$ Dąbek, A. (2021). Polski pacjent zero. Jak się czuje rok po zakażeniu? Medonet.pl

<https://www.medonet.pl/koronawirus/koronawirus-w-polsce,koronawirus-w-polsce--kim-byl-pacjent-zero--jak-sieczuje-,artykul,21379457.html> (2021, Luty, 27).
} 
Rozporządzeniem Ministra Zdrowia z dnia 13 marca 2020 r. na obszarze Rzeczypospolitej Polskiej został ogłoszony stanu zagrożenia epidemicznego ${ }^{1}$.

COVID-19 jest ostrą choroba układu oddechowego wywołana przez nowego ludzkiego koronawirusa (SARS-CoV-2, znany również jako „wirus wywołujący chorobę COVID-19”). Początkowo większość przypadków odnotowano w Chinach i wśród osób, które podróżowały do Chin. Większość stanów wyznaczyła mniej lub bardziej rygorystyczne limity, aby wygładzić krzywą epidemii, tak aby niewiele osób z ciężkim COVID-19 wymagało jednocześnie opieki medycznej i hospitalizacji. W mediach coraz częściej zjawisko wpływu choroby na życie społeczeństwa i jego konsekwencje nazywane jest „koronakryzą" 2 .

Cel pracy, material i metody badawcze. Celem pracy jest analiza wpływu pandemii COVID-19 na funkcjonowanie polskiego społeczeństwa w aspekte opieki paliatywnej. Aby osiągnąć ten cel, przeanalizowaliśmy główne trudności społeczno-ekonomiczne, przed którymi stoi polskie społeczeństwo w związku z pandemią, a także trudności, które trzeba pokonać w zakresie opieki paliatywnej. Do analizy wykorzystaliśmy regulacyjne akty prawne, które zostały przyjęte przez polskie władze w związku z pandemią, a także akty organizacji międzynarodowych, ekspertyzy i publikacje w mediach. Stosowano metodę systemową, prawną porównawczą, obserwacyjną, badania dokumentów, a także inne techniki i metody ogólno-naukowe i specjalne.

Wyniki badań. Pandemia COVID-19 wywołała szereg poważnych konsekwencji społecznogospodarczych, w tym największą globalną recesję od czasu Wielkiego Kryzysu ${ }^{3}$ i masowy głód, który dotknął około 265 milionów ludzi ${ }^{4}$. Doprowadziło to do odroczenia lub odwołania ${ }^{5}$ wielu wydarzeń sportowych, religijnych, politycznych i kulturalnych, praca i nauka ${ }^{6}$ zaczęly odbywać się zdalnie. W związku z tym wzrosło zapotrzebowanie na produkty do domowego biura, a aplikacje do wideokonferencji, takie jak Zoom, Microsoft Teams i ich analogi, cieszą się największą popularnością ${ }^{7}$. Przedłużająca się kwarantanna zmieniła priorytety konsumpcyjne: spadł popyt na szereg dóbr, takich jak towary luksusowe i odzież. Równocześnie gwałtownie wzrósł popyt na artykuły gospodarstwa domowego, zarówno te ułatwiające życie domowe (wypiekacze chleba, multicooker, zamrażarki), jak i na domowe sporty (rowery treningowe, bieżnie) i rozrywkę domową (gry online, gry planszowe).

Wszystkie te tendencje łączy jedno - dystans społeczny. Dystans społeczny odgrywa kluczową rolę w zarządzaniu kryzysowym, ale jest szczególnie trudny dokładnie w czasach kryzysu, kiedy ludzie odczuwają potrzebę spotkania się i wzajemnego wsparcia.

W sytuacji epidemii koronawirusa, gdy systemy opieki zdrowotnej w różnych krajach podejmują doraźne decyzje organizacyjne z powodu braku różnorodnych zasobów, w tym zasobów ludzkich, opieki paliatywnej i jej pacjenci znajdują się w wyjątkowo wrażliwej sytuacji, doświadczając codziennych trudności w zaspokajaniu swoich potrzeb i cele ${ }^{8}$. Zmiany możliwości świadczenia i odbioru usług, zachodzące w ultra krótkim czasie, nie pozwalają na dostosowanie się do nich bez utraty jakości. W tej sytuacji placówki opieki paliatywnej opierają się na «Włączanie opieki paliatywnej i łagodzenia objawów do odpowiedzi na sytuacje

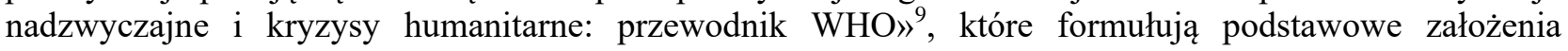

\footnotetext{
${ }^{1}$ Rozporządzenie w sprawie ogłoszenia na obszarze Rzeczypospolitej Polskiej stanu zagrożenia epidemicznego, 2020 (Ministr Zdrowia Rzeczypospolitej Polskiej). Internetowy System Aktów Prawnych <http://isap.sejm.gov.pl/isap.nsf/DocDetails.xsp?id=WDU20200000433> (2021, Luty, 27).

${ }^{2}$ Wikipedia (2021). Коронакризис <https://ru.wikipedia.org/wiki/Коронакризис> (2021, Luty, 27).

${ }^{3}$ International Monetary Fund (2020). Великая самоизолящия: самый глубокий экономический спад со времен Великой депрессии <https://www.imf.org/ru/News/Articles/2020/04/14/blog-weo-the-great-lockdown-worsteconomic-downturn-since-the-great-depression> (2021, Luty, 27).

${ }^{4}$ UN News (2021). As famines of 'biblical proportion' loom, Security Council urged to 'act fast' <https://news.un.org/en/story/2020/04/1062272> (2021, Luty, 27).

${ }^{5}$ The New York Times (2020). A List of What's Been Canceled Because of the Coronavirus $<$ https://www.nytimes.com/article/cancelled-events-coronavirus.html> (2021, Luty, 27).

${ }^{6}$ UNESCO (2021). Education: From disruption to recovery <https://en.unesco.org/covid19/educationresponse> (2021, Luty, 27).

${ }^{7}$ European Commission website (2021). Jobs and economy during the coronavirus pandemic $<$ https://ec.europa.eu/info/live-work-travel-eu/coronavirus-response/jobs-and-economy-during-coronavirus-pandemic_en> (2021, Luty, 27).

${ }^{8}$ Ballentine, J. M. (2020). The Role of Palliative Care in a COVID-19 Pandemic $<$ https://csupalliativecare.org/palliative-care-and-covid-19/> (2021, Luty, 27).

${ }^{9} \mathrm{WHO}$ guide (2018). Integrating palliative care and symptom relief into responses to humanitarian emergencies and crises <https://apps.who.int/iris/bitstream/handle/10665/274565/9789241514460-eng.pdf?sequence=1\&isAllowed=y> (2021, Luty, 27).
} 
organizacji opieki paliatywnej i jej roli w nagłych wypadkach, epidemiach, wojnie. Opieka paliatywna jest również potrzebna w przypadku pacjentów z COVID-19. Zespoły opieki paliatywnej współpracują ze specjalistami w celu złagodzenia duszności, kaszlu, gorączki, duszności i innych objawów typowych dla pacjentów z COVID-19. Są przeszkoleni w zakresie radzenia sobie z powikłaniami, których doświadczają pacjenci z COVID-19 pod koniec życia. Są również przeszkoleni w rozpoznawaniu i leczeniu zespołu majaczenia za pomocą interwencje farmaceutyczne i niefarmaceutyczne.

Ograniczenia kwarantanny, w szczególności związane z wizytą u pacjentów w szpitalach w Polsce zostały wprowadzone jeszcze pod koniec lutego $2020 \mathrm{r}^{1}$. Sytuacja pandemii koronawirusa znacząco skomplikowała i tak już trudną pracę personelu opieki paliatywnej na całym świecie. Opieka paliatywna w pandemii to $\mathrm{z}$ jednej strony system o aktywnie zwiększonych potrzebach i trudnościach, który wymaga niezwykle szybkich rozwiązań, aby pomóc przewlekle chorym, z drugiej strony system, który może aktywnie uczestniczyć $\mathrm{w}$ pomocy pacjentom $\mathrm{z}$ zakażeniem koronawirusem $\mathrm{w}$ w celu zapewnienia jakości życia $\mathrm{i}$ łagodzenia uporczywych dolegliwości bólowych. Pacjenci z ciężkimi, uporczywymi objawami zakażenia koronawirusem mogą wymagać opieki paliatywnej. W sytuacji epidemii specjaliści opieki paliatywnej mogą być skutecznie poszukiwani na oddziałach intensywnej terapii i oddziałach intensywnej terapii do pracy z ciężkimi pacjentami. Potrzeba ta może stać się szczególnie dotkliwa w przypadku zwiększonego przepływu pacjentów z ciężkimi objawami i złymi rokowaniami na powrót do zdrowia. Zgodnie z zaleceniami WHO, w nagłych wypadkach, w przypadku pandemii, służby opieki paliatywnej powinny być zaangażowane w pomoc osobom dotkniętym chorobą $\mathrm{i}$ ich rodzinom ${ }^{2}$. Terminowa identyfikacja pacjentów wymagających specjalistycznej opieki poprawi jakość usług świadczonych na najpoważniejszej grupie pacjentów. Komfort, dotyk, poczucie wspólnoty: to jedne z kluczowych elementów opieki hospicyjnej - opieki oferowanej u schyłku życia. Te same zasady stoją również w bezpośredniej sprzeczności z dystansem i separacją, które są konieczne podczas pandemii.

Główne problemy, które pojawiły się w systemie sprawowania opieki paliatywno-hospicyjnej w Polsce w okresie pandemii, można podzielić na: organizacyjno-ekonomiczne, terapeutyczno-diagnostyczne i psychospołeczne.

Problemy organizacyjno-ekonomiczne:

- przypadki reorganizacji i przeprofilowania organizacji świadczących opiekę paliatywną w celu zapewnienia opieki medycznej ludności w pandemii;

- przeciążenie systemu opieki zdrowotnej;

-złożoność wyposażenia personelu medycznego w sprzęt ochrony osobistej i środki dezynfekujące;

- pogłębianie się niedoborów kadrowych pracowników medycznych związanych z zakażeniem

COVID-19, leczeniem i wypaleniem zawodowym;

- potrzeba w ograniczonym czasie ukształtowania kompetencji zawodowych w zwalczaniu pandemii wśród personelu medycznego służb paliatywnych;

-zakończenie przyjmowania do organizacji szpitalnych zapewniających opiekę paliatywną, krewnych, przyjaciół pacjentów i wolontariuszy, co prowadzi do dodatkowego obciążenia personelu;

- Ograniczenie lub zakończenie wizyt domowych u pacjentów przez mobilne zespoły patronackie;

-znaczny spadek finansowania;

-wysoki poziom popytu na internetowe formy interakcji między pracownikiem - pracownikiem, pracownikiem - rodziną, rodziną - pacjentem itd.

Problemy terapeutyczno-diagnostyczne:

- komplikacja logistyki zaopatrzenia pacjentów w leki, w tym środki odurzające i psychotropowe;

- duże zapotrzebowanie służby zdrowia na środki do sztucznej wentylacji płuc i koncentratory tlenu dla chorych, w tym kosztem środków systemu opieki paliatywnej;

-zwiększony popyt rynkowy na szereg leków, produktów i materiałów eksploatacyjnych, które są potrzebne w systemie opieki paliatywnej;

-ostre ograniczenie możliwości diagnostycznych i innych dla pacjentów korzystających z opieki paliatywnej w warunkach ambulatoryjnych;

-zwiększone ryzyko infekcji u pacjentów paliatywnych.

\footnotetext{
${ }^{1}$ Poznan (2020). Koronawirus w Polsce? Coraz więcej ograniczeń w szpitalach. Zakazy odwiedzin u pacjentów <https://www.se.pl/poznan/koronawirus-w-polsce-relacja-na-zywo-aa-vDoh-nRwb-ewyD.html> (2021, Luty, 27).

${ }^{2}$ WHO guide (2018). Palliative care for people affected by epidemics of lifethreatening infections. - Integrating palliative care and symptom relief into responses to humanitarian emergencies and crises <https://apps.who.int/iris/handle/10665/274565> (2021, Luty, 27).
} 
Problemy psychospołeczne:

-zwiększenie liczby stresorów dla personelu opieki paliatywnej i rodzin pacjentów podczas kwarantanny;

- naruszenie zwykłego trybu życia i radzenie sobie ze stresem, lęk przed zarażeniem siebie i innych, izolacja społeczna;

- dodatkowe obciążenie psychiczne związane z długotrwałą sytuacją zagrożenia i niepewności;

- konieczność ciągłego stosowania środków ochrony indywidualnej w kontakcie z innymi ludźmi;

- stygmatyzacja osób zakażonych, strach i podejrzliwość.

W przeciwieństwie do szpitali, hospicja i oddziały opieki paliatywnej nie mogą całkowicie zakazać wizyt pacjentów. Osobliwością hospicjach jest to, że bardzo często oni nie mają jutro, jest tylko tu i teraz. Byłoby to nieludzkie, bo ta wizyta może być ostatnią szansą na spotkanie z bliskimi. Dla pacjentów paliatywnych i ich rodzin zakaz wizyt stał się niezwykle stresujący. Jedną z głównych zasad opieki paliatywnej jest to, że pacjent i jego bliscy są jednym, a niemożność pożegnania się z umierającą staje się największym stresem zarówno dla pacjenta, jak i jego rodziny. Jedyne, co można zrobić, to zmniejszyć liczbę odwiedzających do jednej osoby dziennie na każdego pacjenta. Zakaz wizyt szpitalnych ogranicza możliwości odwiedzin wielu świadczeniodawców opieki paliatywnej, takich jak wolontariusze, księża, filantropi, organizacje non-profit i wyznaniowe, co wpływa na wdrażanie multidyscyplinarnego podejścia oraz duchowego i społecznego wsparcia dla pacjentów i ich rodzin. Tym samym usługi systemu opieki paliatywnej nabierają konotacji czysto medycznej. Personel hospicjum stanął w obliczu dodatkowych obciążeń związanych z brakiem pomocy ze strony inni uczestnicy opieki paliatywnej, a także koniecznością przestrzegania zaostrzonych środków ochrony epidemiologicznej. Dodatkowo dodano odpowiedzialność za organizację zdalnej komunikacji z pacjentami za pomocą połączeń telefonicznych i wideo z wykorzystaniem technologii internetowych. Należy zauważyć, że Amerykańskie Centra Kontroli i Zapobiegania Chorobom, w swoich wytycznych dla domów opieki nad COVID-19, stwierdza, że „wszystkie wizyty powinny być ograniczone, z wyjątkiem sytuacji związanych ze współczuciem, takich jak koniec życia"”.

Wnioski. Można stwierdzić, że dotkliwość pandemii COVID-19 w Polsce doprowadziła do ograniczenia świadczenia opieki paliatywnej. W warunkach ograniczonych zasobów zdarzają się przypadki, gdy lekarze opieki paliatywnej i pielęgniarki są wysyłani, aby zapewnić opiekę w nagłych wypadkach pacjentom z COVID-19. Ważnym czynnikiem jest spadek liczby wolontariuszy i sponsorów, którzy są gotowi zapewnić środki finansowe i ludzkie dla sektora opieki paliatywnej, ponieważ część z tych osób przekwalifikowała się do walki z COVID-19. We wszystkich regionach kraju zaszły zmiany w zakresie obserwacji pacjentów w domu. Wizyty mobilnych zespołów paliatywnych były maksymalnie ograniczone. Znaczna część prac: monitorowanie stanu, dostosowywanie schematu leczenia, uczenie bliskich umiejętności opiekuńczych zostały przeniesione na format zdalny. Dlatego też inna podstawowa zasada opieki paliatywnej - całodobowe wsparcie rodziny jest również trudna, zwłaszcza biorąc pod uwagę zatory w podstawowej opiece zdrowotnej. Ogromnie wzrosło obciążenie psychologiczne lekarzy i pielęgniarek. Muszą radzić sobie $\mathrm{z}$ własnym przepływem, zastępując się jak w kalejdoskopie emocji (związanych z szokiem, niepewnością i niepewnością, poczuciem zagrożenia i niepewności, czasem własnym brakiem praw, stresem fizycznym i emocjonalnym). Trudne reakcje emocjonalne i doświadczenia pacjentów i ich bliskich nakładają się również na doświadczenia lekarzy związane z adaptacją do nowych warunków pracy.

Podziękowania. Pragnę wyrazić moją wdzięczność Fundacji Liderzy Przemian i Programu Stypendialnemu im. Lane'a Kirklanda za organizacyjne i finansowe wsparcie moich badań. Serdecznie dziękuję również za cenne uwagi i możliwość konsultacji mojemu opiekunowi naukowemu dr. hab. Włodzimierzu Piątkowskiemu, a także kierownictwu UMCS za możliwość przeprowadzenia badań.

\section{References:}

1. Robin Bhatty and Rachel Bronson, NATO,Mixed signalsin the Caucasus and Central Azia. Vol.42,N3. Autumn, 2000

2. Ballentine, J. M. (2020). The Role of Palliative Care in a COVID-19 Pandemic $<$ https://csupalliativecare.org/palliative-care-and-covid-19/> (2021, February, 27). [in English].

3. CDC (2020). Interim Additional Guidance for Infection Prevention and Control for Patients with Suspected or Confirmed COVID-19 in Nursing Homes <https://www.cdc.gov/coronavirus/2019-ncov/hcp/dialysis.html> (2021, February, 27). [in English].

\footnotetext{
${ }^{1}$ CDC (2020). Interim Additional Guidance for Infection Prevention and Control for Patients with Suspected or Confirmed COVID-19 in Nursing Homes <https://www.cdc.gov/coronavirus/2019-ncov/hcp/dialysis.html> (2021, Luty, 27).
} 
4. Dabek, A. (2021). Polski pacjent zero. Jak się czuje rok po zakażeniu? [Polish patient zero. How does it feel a year after infection?] Medonet.pl <https://www.medonet.pl/koronawirus/koronawirus-w-polsce,koronawirus-w-polsce-kim-byl-pacjent-zero--jak-sie-czuje-,artykul,21379457.html> (2021, February, 27). [in Polish].

5. European Commission website (2021). Jobs and economy during the coronavirus pandemic <https://ec.europa.eu/info/live-work-travel-eu/coronavirus-response/jobs-and-economy-during-coronavirus-pandemic_en> (2021, February, 27). [in English].

6. International Monetary Fund (2020). Velikaya samoizolyatsiya: samyy glubokiy ekonomicheskiy spad so vremen Velikoy depressii [The Great Self-Isolation: The Deepest Recession Since the Great Depression] <https://www.imf.org/ru/News/Articles/2020/04/14/blog-weo-the-great-lockdown-worst-economic-downturnsince-the-great-depression> (2021, February, 27). [in Russiun].

7. Medonet.pl (2020). WHO ogłasza stan zagrożenia zdrowia publicznego o znaczeniu międzynarodowym [WHO declares a public health emergency of international concern] <https://www.medonet.pl/zdrowie,who-oglasza-stanzagrozenia-zdrowia-publicznego-o-znaczeniu-miedzynarodowym,artykul,64750229.html> (2021, February, 27). [in Polish].

8. Poznan (2020). Koronawirus w Polsce? Coraz więcej ograniczeń w szpitalach. Zakazy odwiedzin u pacjentów [Coronavirus in Poland? More and more restrictions in hospitals. Visiting bans for patients] <https://www.se.pl/poznan/koronawirus-w-polsce-relacja-na-zywo-aa-vDoh-nRwb-ewyD.html> (2021, February, 27). [in Polish].

9. Rozporządzenie w sprawie ogłoszenia na obszarze Rzeczypospolitej Polskiej stanu zagrożenia epidemicznego, 2020 (Ministr Zdrowia Rzeczypospolitej Polskiej) [Regulation on the declaration of an epidemic emergency in the territory of the Republic of Poland, 2020 (Minister of Health of the Republic of Poland)]. Internetowy System Aktów Prawnych [Internet System of Legal Acts] <http://isap.sejm.gov.pl/isap.nsf/DocDetails.xsp?id=WDU20200000433> (2021, February, 27). [in Polish].

10. The New York Times (2020). A List of What's Been Canceled Because of the Coronavirus $<$ https://www.nytimes.com/article/cancelled-events-coronavirus.html> (2021, February, 27). [in English].

11. UN News (2021). As famines of 'biblical proportion' loom, Security Council urged to 'act fast' <https://news.un.org/en/story/2020/04/1062272> (2021, February, 27). [in English].

12. UNESCO (2021). Education: From disruption to recovery <https://en.unesco.org/covid19/educationresponse> (2021, February, 27). [in English].

13. WHO guide (2018). Integrating palliative care and symptom relief into responses to humanitarian emergencies and crises <https://apps.who.int/iris/bitstream/handle/10665/274565/9789241514460eng.pdf?sequence $=1 \&$ isAllowed $=\mathrm{y}>$ (2021, February, 27). [in English].

14. WHO guide (2018). Palliative care for people affected by epidemics of lifethreatening infections. - Integrating palliative care and symptom relief into responses to humanitarian emergencies and crises <https://apps.who.int/iris/handle/10665/274565> (2021, February, 27). [in English].

15. Wikipedia (2021). Koronakrizis [Coronacrisis] <https://ru.wikipedia.org/wiki/Коронакризис> (2021, February, 27). [in Russiun]. 